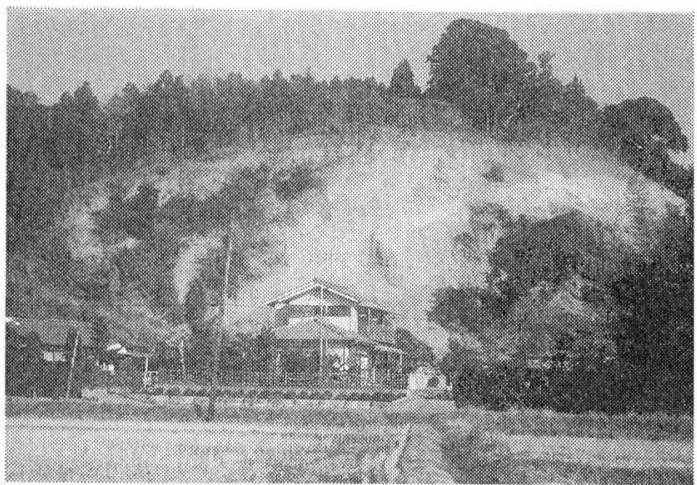

図-7 崖崩れ危険地（成東町富田）

る（例：成東町真行寺, 昭60.12.24日付け千葉県告示第 1276号）ことがわかった。

\section{5. 要 約}

単純な比較は困難であるが，粘性土の地すべり地帯は 地震災害が少なく，粒径のそろった砂質土の急崖は危険 性が高い。また，樹高の大きい植生は地盤破壊を促進す

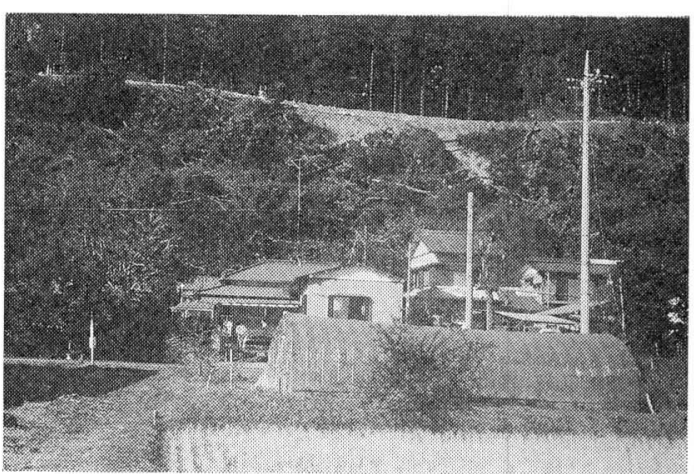

図-8＼cjkstart崖崩れ危険地（成東町津辺本村）

る。

参考文献

1) 気象庁資料

2）千葉日報抢よび NHK 報道番組

3）土質工学会基準(1981)：硬さによる地山しらすの判別介類 法(JSF 規格：M 2-81)，土と基礎 29(4)，45 48

\title{
千葉県東方沖地震による山地災害とその対応一速報一
}

北部林業事務所

山武土木事務所

1987年12月17日11時08分に発生した千葉県東方沖の北 緯 $35^{\circ} 21^{\prime}$, 東経 $140^{\circ} 29^{\prime}$ に震源を持つM 6.7 の地震によ り, 祘下各地飞被害が発生し, 特に斜面崩壊は山武郡松 尾町, 成東町, 東金市の九十九里平野に面する台地の周 縁部と, 震源地に近い長生郡長南町の丘陵地带に集中し た（表-1 被害状況表, 図-1 市町村位置図)。

崩壊現象の形態は亀裂が著しく多いのが特徵で, 今回 の斜面崩壊による被害は, 時間が経過するとともに拡大 した。

成東町津辺では, 地震発生から 2 日後の19日に斜面崩
壊が発生し，11世帯 46 人が夜半に避難するとともに，松 尾町田越でも亀裂が拡大し， 20 日午後 20 世帯 73 人が避難 した。

斜面崩壊の発生は地震動の集中した崖の端に亀裂が発 生したことから始まり, この亀裂から滑落, 崩落にまで 達する過程は斜面条件によって図一2のと叔り I滑落タイ プ，IIトリッピングタイプ，正クリーピング滑落タイプ， IV 表層滑動崩落の 4 つの過程に整理され, 詳細につい ては現在調査を実施し解析中である。

県としての山地苂害防止対策は, 再崩壊を事前に予知

表-1 昭和62年12月17日午前11時08分ごろ発生の地震による被害状況

総務部消防防災課 昭和 63 年 1 月 5 日 13 時 00 分現在

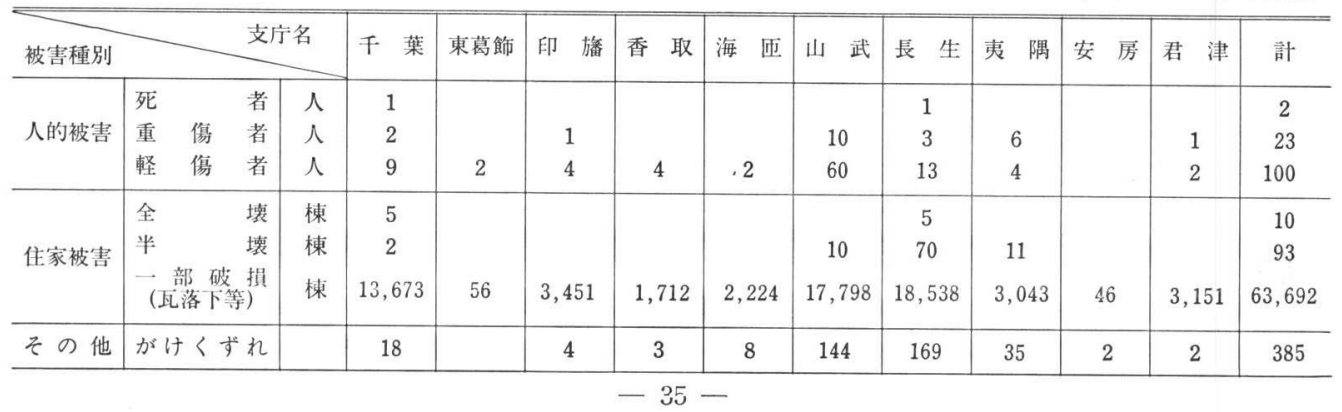




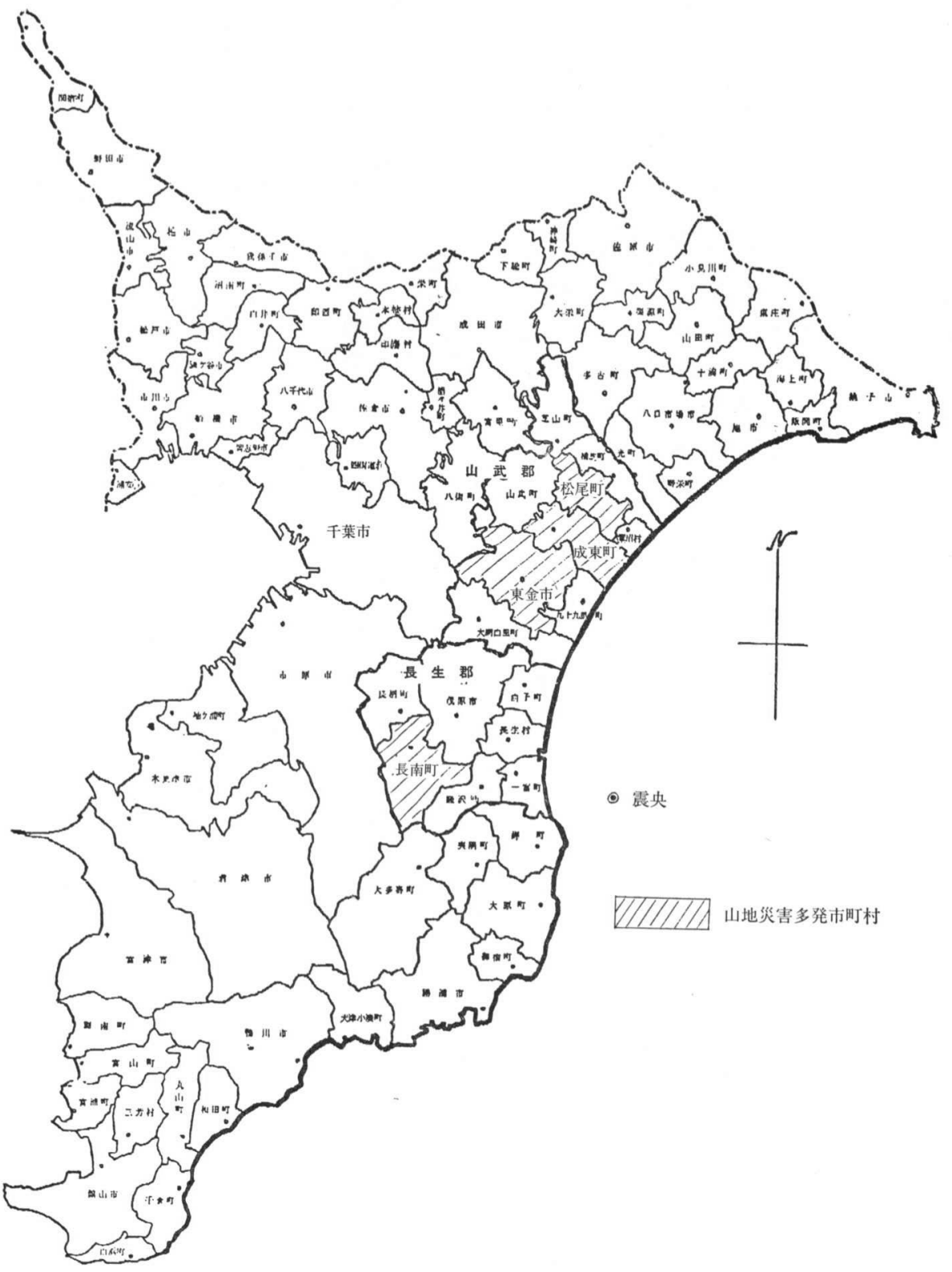

図-1 市町村位置図

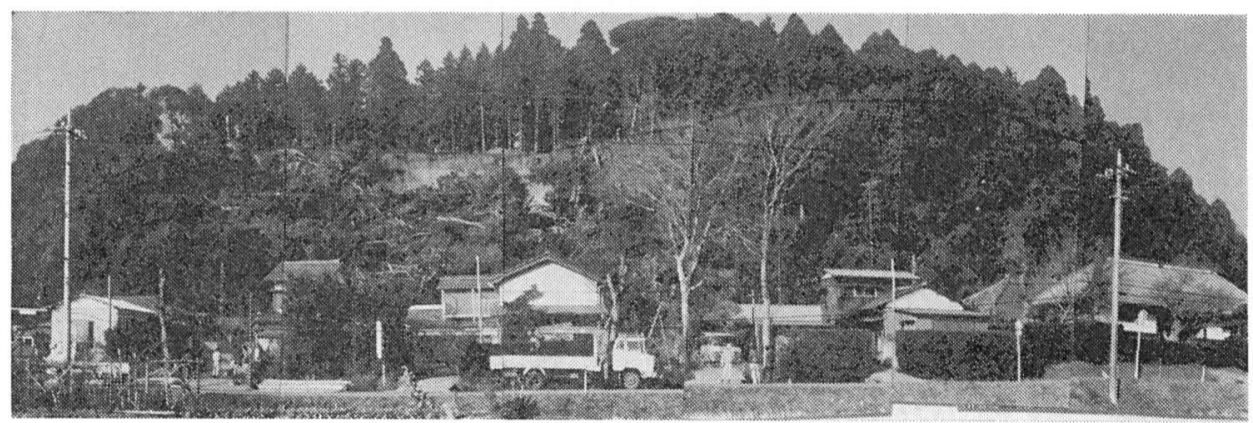

山武郡成東町津辺 


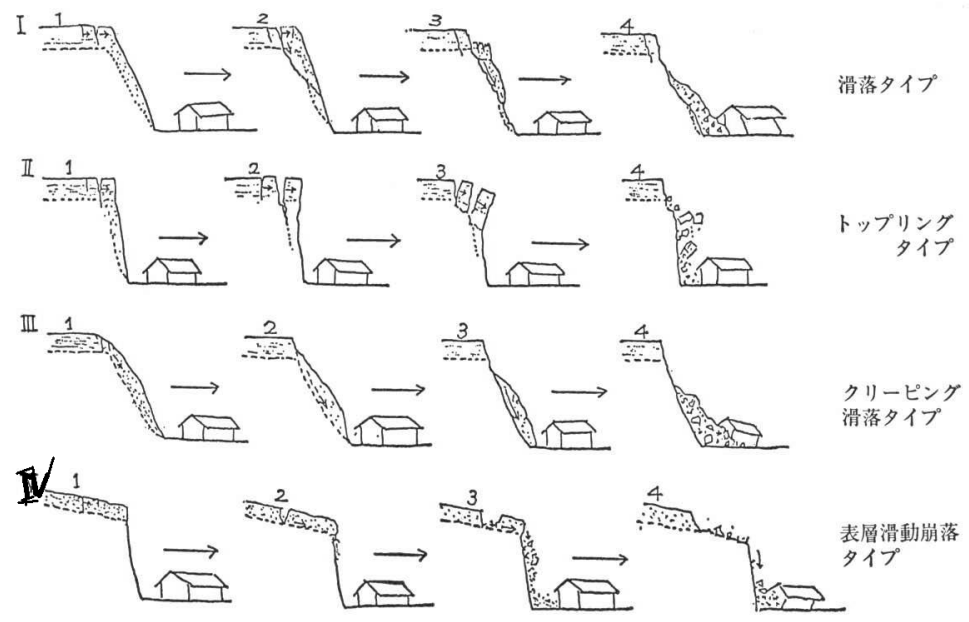

図-2 龟裂から崩壊にいたる過程の模式図（古屋尊彦 1988.1.6）

するため，伸縮計を設置し，監視を開始するとともに， 応急工事として, (1)危険樹木の伐倒搬出, (2)不安定土砂 の排除, (3)シートによる亀裂の被覆, (4)仮設防護佣の設 置等を実施した。

今後は，恒久的な防災工事として，保安林に打いては 災害関連緊急治山事業，急傾斜地崩壊危険区域に打いて は緊急急傾斜地崩壊対策事業を昭和62年度事業として実 施し，早期完成を図ることとしている。

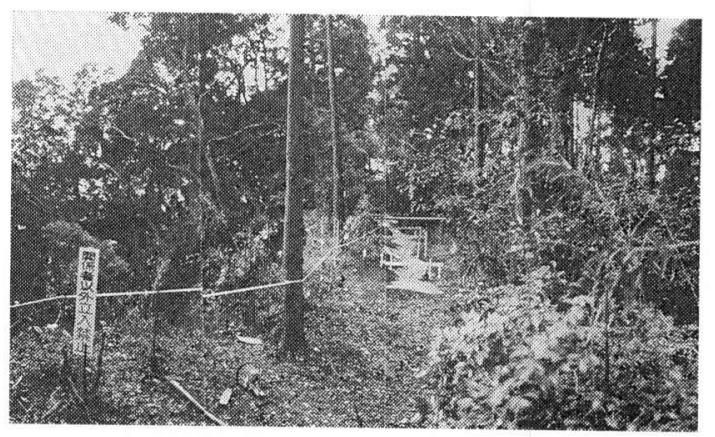

山武郡成東町津辺

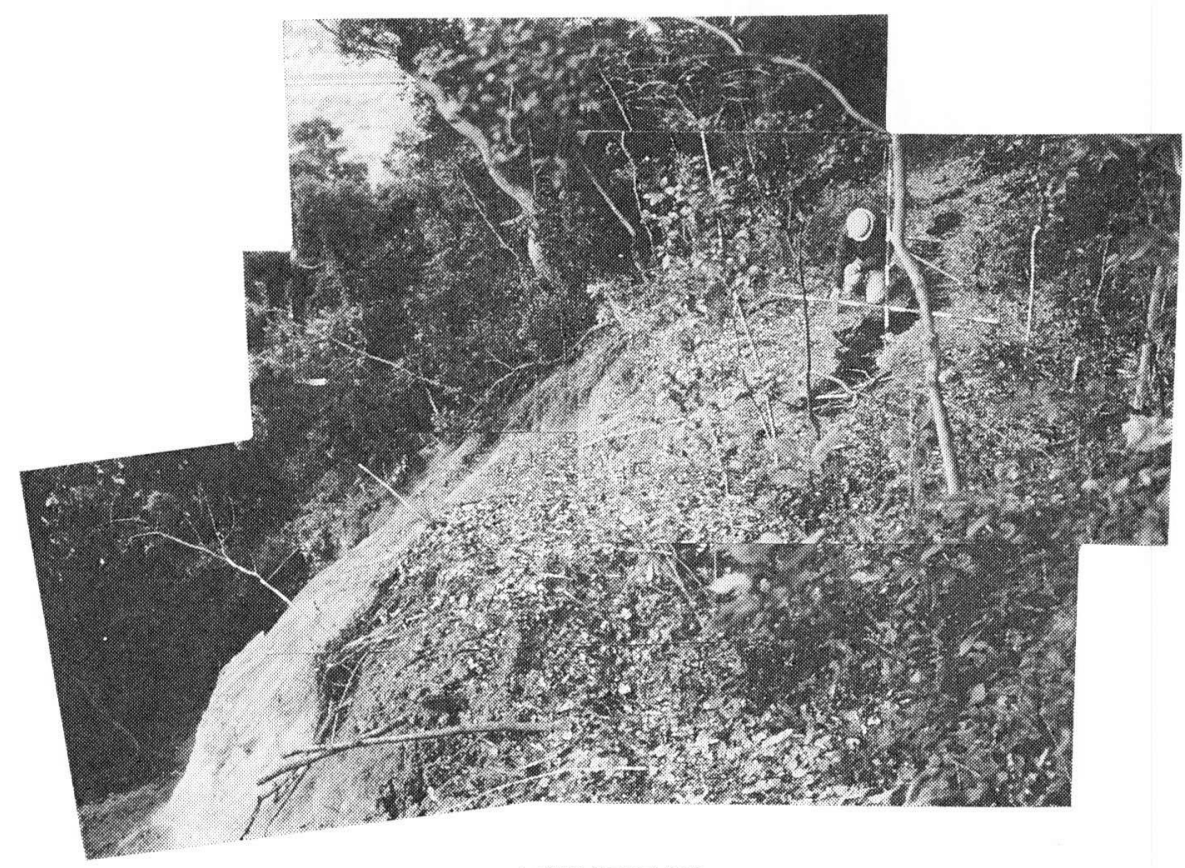

山武郡成東町成東 


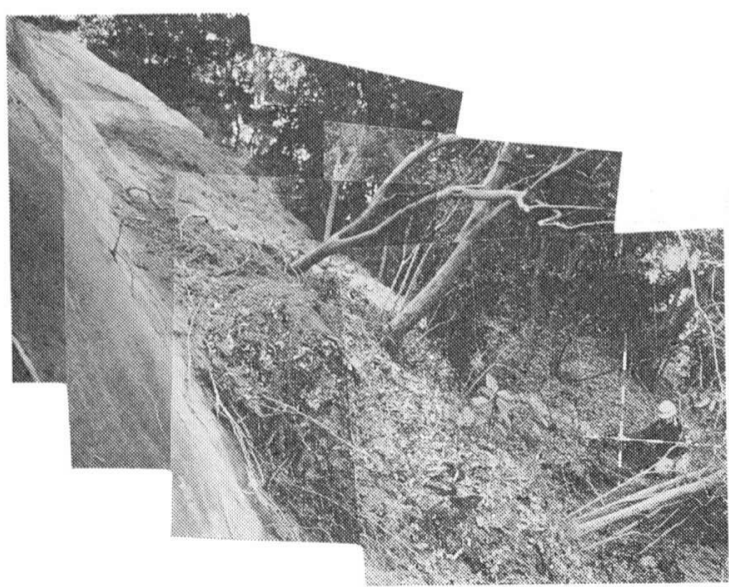

山武郡成東町成東

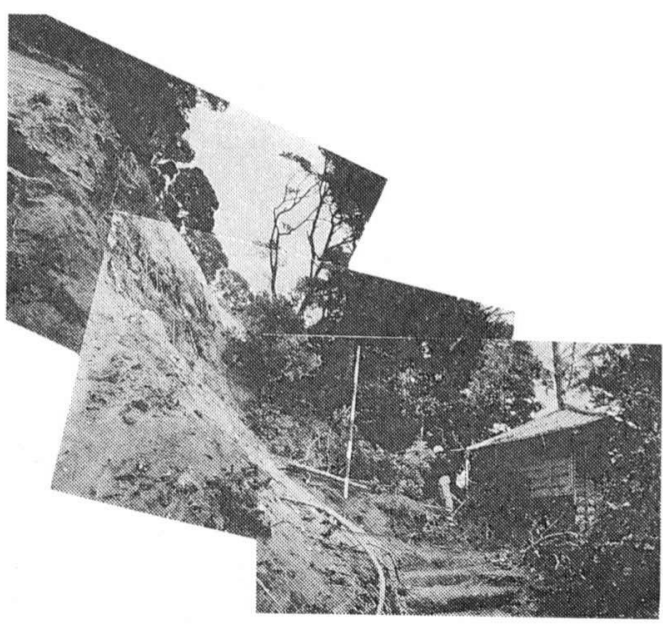

山武郡成東町成東

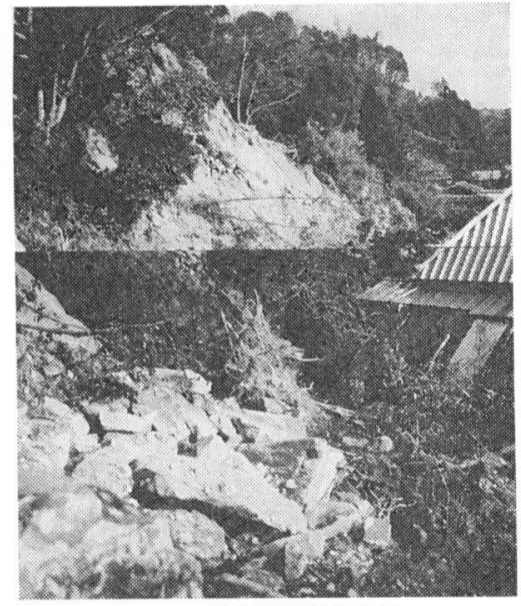

長生郡長南町佐坪

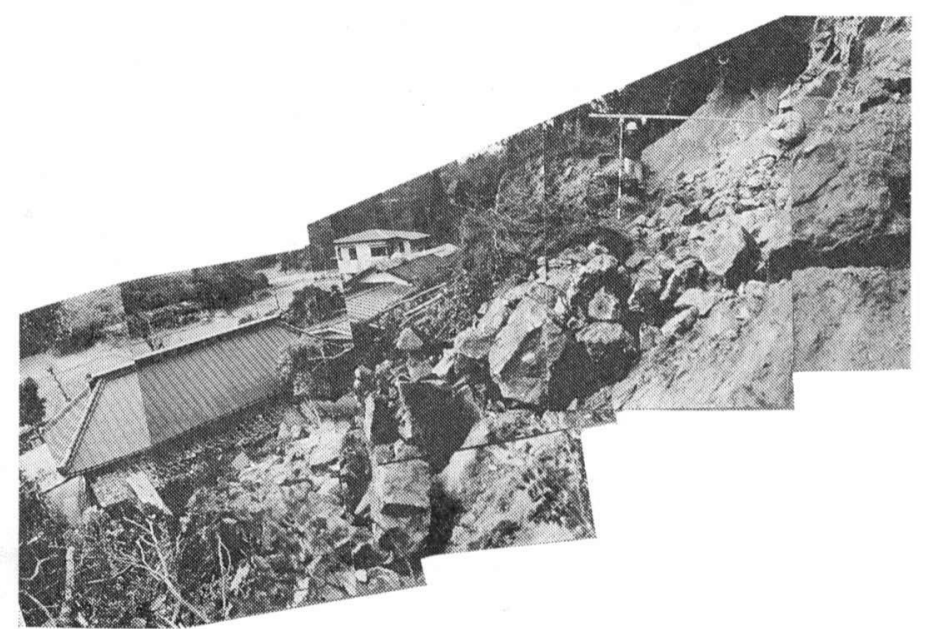

長生郡長南町佐坪

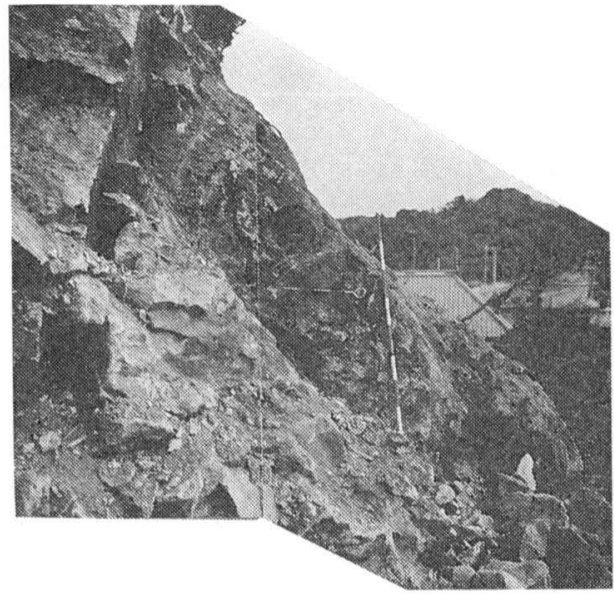

長生郡長南町佐坪

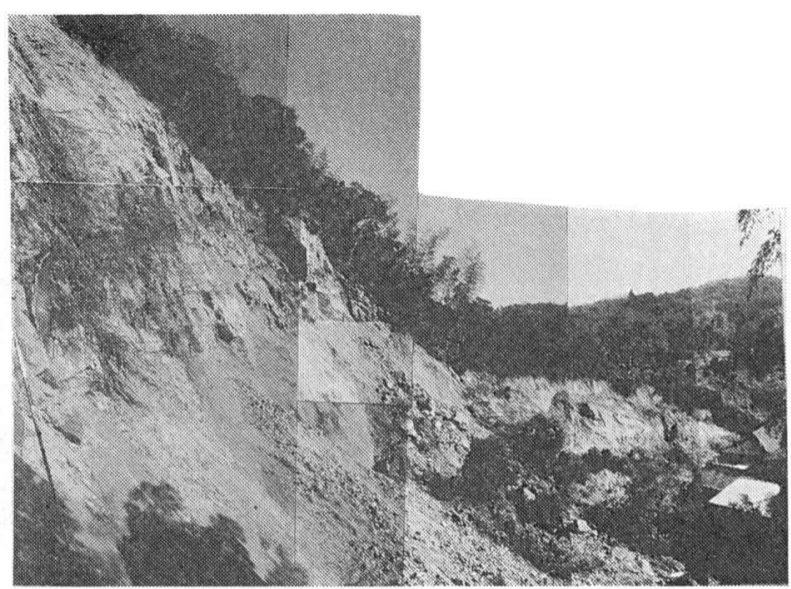

長生郡長南町上小野田 